\title{
Ergonomic interventions to improve work environment in garment manufacturing units
}

\begin{abstract}
The work environment in the garment manufacturing units is unhealthy and unsafe for the workers, resulting in several health problems. Analysis of garment manufacturing units using a combination of techniques revealed that the congested work area, improper ventilation, dust, unergonomic workstations, excessive noise and non-use of personal protective equipment were the major constraints faced by the workers in these units. Based on the study, interventions to improve the work environment, safety aspects and work methods have been suggested which could be adopted on a wider scale.
\end{abstract}

Key words: Garment manufacturing units, guidelines, safety aspects, work environment

\section{INTRODUCTION}

In India, the readymade garment industry had its beginning during the first half of the $20^{\text {th }}$ century and has witnessed impressive growth during the last four decades. It is reported to be the second highest contributor to India's export basket, after 'gems and jewelry."[1] There are around 70,000 garment manufacturing units in the country providing employment to more than 3 million persons. ${ }^{[2]}$

The work environment in a majority of these units is unsafe and unhealthy. These include poorly designed workstations, unsuitable furniture, lack of ventilation, inappropriate lighting, excessive noise, insufficient protection from dangerous chemicals, insufficient safety measures in fire emergencies and lack of personal protective equipment. People working in such poor or substandard environment are prone to occupational diseases.

Empirical evidences suggest that the workers in the garment units suffer from work-related musculoskeletal disorders such as carpal tunnel syndrome, forearm tendinitis, epicondylitis, bicapital tendinitis, lower back pain, neck pain, shoulder pain and osteoarthritis of the knees. ${ }^{[3-7]}$ Mismatch between man and machine is one of the major factors contributing to musculoskeletal problems. This may be mainly due to the attempts made by the workers to 'fit the man to the job' rather than to 'fit the job to the man'. The recent efforts in this area are directed to fitting the job to the man by eliminating mismatch between the man and the machine and redesigning the work environment to the optimum comfort levels of the workers. The present study aims at suggesting interventions to provide better work environment in the garment manufacturing units, which is the outcome of the in depth analysis of work and work environment.

\section{MATERIALS AND METHODS}

The study was conducted in 18 garment manufacturing units located in Madurai city. A total of 216 workers from these 18 garment manufacturing units formed the study sample. Various methods like interview with the workers; analysis of work environment $_{i}$ hazard identification and risk assessment; and quantification techniques were used to collect information about the work, work environment and workers health problems. By the combination of these techniques, several gaps were identified in the work environment and facilities provided to the workers. Based on the study, ergonomic interventions have been suggested which will eventually help to improve the work environment and also to overcome the health problems.

\section{RESULTS AND DISCUSSIONS}

The results of the study revealed that there had been several gaps in work environment, tools and equipment that affect the health and safety of workers at the work site. Table 1
P. Parimalam, N. Kamalamma*, A. K. Ganguli** Department of Family Resource Management, Home Science College and Research Institute, Tamil Nadu

Agricultural University, Madurai, *Department of Home Science, Gandhigram Rural Institute (Deemed University), Gandhigram,

** Occupational Health Services, Bharat Heavy Electricals Limited, Tiruchirapalli, India

For correspondence: Parimalam Paramasivam, Plot No. 105, Kalainagar Colony, Madurai - 625017 , India.

E-mail: parimalamkannan@ hotmail.com

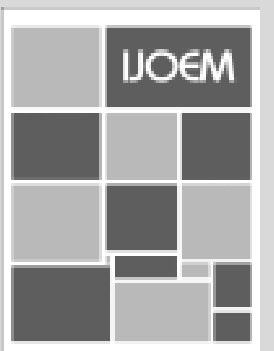


presents the gaps identified in the work environment.

The mean heights of the tables used for cutting, sorting, checking and ironing were 99.5, 92.3, 89.9 and $92.3 \mathrm{~cm}$ respectively. The furniture used in the garment manufacturing units was either above or below the recommended levels and the strained posture had to be maintained throughout the work day, which could have been responsible for the development of pain in the shoulders, the upper arm and the forearm. The high stool (mean height $59.5 \mathrm{~cm}$ ) forced the workers to bend their trunk and head toward the table to have a clear view of the point of operation. As a result of excessive bending, a majority of workers complained of pain in the lower back, the mid back, the shoulders and the neck. The stools used by the operators were not padded for their comfort when seated for long hours. None of the work stools had a backrest to provide support to the back.

The mean levels of illumination in the cutting and stitching sections were of 259.88 and 236.05 lx respectively. This was found to be low when compared to the standard levels recommended by Grandjean, ${ }_{1}^{[8]}$ and Ghosal, ${ }_{1}^{[9]}$ which are 750 and $400 \mathrm{~lx}$ respectively. Due to improper selection of lighting fixtures and their placements, the efforts made to improve the levels of illumination had failed to give the desired results at the point of operation.

Continuous exposure to high levels of noise over a period of time would result in noise-induced loss of hearing among the workers in this section. Improper maintenance of the machines also added to the mechanical noise. Excessive dust was reported as a problem by $27 \%$ of the workers in the cutting section. The occupational health survey revealed a high rate (85.2\%) of prevalence of breathing difficulty and $22 \%$ of the workers in the cutting section suffered from asthma. Due to continuous use of steam iron, the finishing section was found

Table 1: Gaps identified in work environment

\begin{tabular}{|c|c|c|}
\hline Areas & Gaps identified & Supportive findings \\
\hline \multicolumn{3}{|l|}{ Furniture } \\
\hline Cutting table & Work height too high & Complaints of postural \\
\hline Sorting table & Work height too high & discomfort and pain in \\
\hline Inspection table & Work height too low & shoulders, neck and hands \\
\hline Ironing table & Work height too low & \\
\hline $\begin{array}{l}\text { Sewing machine operators } \\
\text { stool }\end{array}$ & Too high & \\
\hline \multicolumn{3}{|l|}{ Workspace/environment } \\
\hline Inadequate lighting & Low level of lighting & $\begin{array}{l}\text { Complaints of visual strain } \\
\text { and blurred vision }\end{array}$ \\
\hline Excessive noise & $\begin{array}{l}\text { Noise level exceeds } \\
90 \mathrm{~dB}(\mathrm{~A})\end{array}$ & Worker's complaints \\
\hline Dust & $\begin{array}{l}\text { Increased level in } \\
\text { cutting section }\end{array}$ & $\begin{array}{l}\text { Complaints of respiratory } \\
\text { problems }\end{array}$ \\
\hline Hot and humid work place & Humidity 23 to $57 \%$ & Workers complaints \\
\hline Heat & Heat exposure & $\begin{array}{l}\text { Identified as risk factor } \\
\text { by hazard identification } \\
\text { and risk assessment }\end{array}$ \\
\hline
\end{tabular}

to be hot and humid. The humidity levels in the units ranged from 23 to 57\%, with the highest levels recorded for the finishing section. The workers' response to questions regarding temperature also supported this view [Table 1].

Table 2 summarizes the gaps in the design and usage of tools and equipment and also in safety aspects at work site. Cases of accidental injury to fingers while working with the handheld cutting machine and the band knife cutting machine were reported by $52 \%$ of the workers in the cutting section. Though there were inbuilt blade guards for these machines, they were too small and inadequate to provide safety to the fingers placed on top of the fabric for holding the fabric layers in position. Some of the operators did not care to use blade guards while operating the machines. This has led to accidental injuries and cuts on fingertips in a few cases.

Continuous use of cutting shears has led to swelling of fingers and cornifications of the skin of the fingers. Many of the workers in the cutting section used to wrap the handles of the shears with a piece of cloth/cotton to reduce the friction of the metallic handle on the muscles and the resultant pain.

Lack of task lighting (local lighting) was an important deficiency noticed in the sewing machine. The workers complained of headache and occurrence of accidents like needle-piercing because of the visual strain caused by insufficient light at the point of operation. The hazard identification and risk analysis indicated insufficient illumination as a risk for the sewing machine operators.

Lack of general safety measures like absence of first aid kits and lack of safety devices like fire extinguishers, alarms and emergency exits were other serious deficiencies in the workplace. Lack of these safety devices results in the workers getting trapped inside the units under emergency situations. None of the cutting machine operators used any personal protective equipment like metallic gloves for safeguarding the hands from possible mechanical injuries. The risk of cuts in fingers can be easily avoided with this simple device.

\section{Table 2: Gaps identified in equipment and tools}

\begin{tabular}{|c|c|c|}
\hline Areas & Identified gaps & Supportive findings \\
\hline \multicolumn{3}{|l|}{ Equipment and tools } \\
\hline $\begin{array}{l}\text { Blade guard of the } \\
\text { cutting machine }\end{array}$ & $\begin{array}{l}\text { Defects in design of } \\
\text { blade guard, non use } \\
\text { of blade guards }\end{array}$ & $\begin{array}{l}\text { Fifty per cent of workers } \\
\text { reported accidental cuts }\end{array}$ \\
\hline $\begin{array}{l}\text { Shears used for fabric } \\
\text { cutting }\end{array}$ & $\begin{array}{l}\text { Handles heavy and } \\
\text { strenuous to use for long }\end{array}$ & $\begin{array}{l}\text { Swollen fingers and } \\
\text { cornifications }\end{array}$ \\
\hline Sewing machine & Absence of task lighting & Postural discomfort \\
\hline \multicolumn{3}{|l|}{ Safety at work site } \\
\hline General safety measure & $\begin{array}{l}\text { Absence of general safety } \\
\text { measures }\end{array}$ & Observed gaps \\
\hline $\begin{array}{l}\text { Personal protective } \\
\text { equipment }\end{array}$ & $\begin{array}{l}\text { Absence of personal } \\
\text { protective devices }\end{array}$ & $\begin{array}{l}\text { Observation and } \\
\text { reported incidences }\end{array}$ \\
\hline
\end{tabular}




\section{Suggestions to improve work environment}

The suggestions that have emerged from the present study have been formulated as guidelines. These guidelines would not only be of use for improving the work environment in existing units from the health and safety point of view but would also be invaluable for entrepreneurs starting new units.

The dimensions suggested for various tables used in readymade garment units are given in Table 3 . As multiple tasks like pattern laying, pattern marking and cutting are carried out on the same table, a height-adjustable wooden platform is suggested as an adjunct to the cutting table for adjusting the work height for various operations. The wooden platform will also help in preventing electrical shocks while operating electrical instruments.

The inspection table should have a forward inclination of $12^{\circ}$ towards the worker to enable the workers to have a clear view of the garment being examined and to maintain postural stability while at work. The table top can be covered with a rough cloth to prevent slipping of the garments. The use of wooden platforms to stand on while ironing should be insisted on. The recommended dimensions of the sewing machine operator's work seat height should be $41.5 \mathrm{~cm}$ for women and $43 \mathrm{~cm}$ for men to attain a $105^{\circ}$ trunk-thigh angle while operating the sewing pedal. The seat should be padded or wire-netted to provide comfort to the worker.

A minimum lighting level of $400 \mathrm{~lx}$ is recommended for all the three sections of the readymade garment manufacturing units. For sewing operations, additional task lighting is to be provided in the machine in such a way that the visibility of the needlepoints will be optimum. Lighting in the sewing section is to be planned functionally and the lights fixed at appropriate points to ensure optimum lighting at the work site.

Noise control at the source can be ensured by regular maintenance, lubrication and replacement of parts that produce noise in the embroidery machines. Use of earplugs/ earmuffs by workers in the embroidery section can be made obligatory. Workers exposed to high noise levels should be provided with ear protection or their working periods rotated so that they remain within the permissible limit of 4 hours' exposure to $95.0 \mathrm{~dB}(\mathrm{~A})$.
Provision of local exhaust ventilation that uses suction, based on the principle of a vacuum cleaner, is to be encouraged in the cutting and stitching sections to remove dust from the air. The dust particles can be sucked through the ventilation duct provided in all the three sections of the readymade garment units. Workers in the cutting and the stitching sections should be encouraged to use dust protectors in the form of fine-mesh cloth material worn over the face and the nose, similar to operation theater staff, while at work, especially when knitted materials are used for garment making. A gap of 4-5 feet between rows of machines will minimize the workers' exposure to heat from the sewing machine motor.

The blade guards of the cutting machines are to be redesigned. These guards can be designed either as enclosure guards or as interlocking guards. Enclosure guards will cover the entire blade. Interlocking guards will allow the machine to function only after the blade guards are lowered. Tools like shears used for fabric cutting need to be redesigned. The handles should be made of flexible polyethylene materials, which even after prolonged and regular use give a comfortable feel.

Every unit should have at least the minimum first aid facilities and access to trained personnel to provide emergency medical care. First aid facilities and trained personnel are important components of health and safety arrangement. Safety measures should be checked periodically for ensuring their utility during emergency situations. Use of personal protective equipment (PPE) like earplugs, earmuffs and dust masks should be made mandatory wherever threat to workers' health and safety is anticipated. All workers using PPE should be trained in their use and maintenance. While purchasing PPE, items that have been designed in accordance with recognized standards set by relevant institutions should be bought - ISIapproved if existing.

\section{CONCLUSION}

These interventions made in the units would help to improve the work environment of the garment manufacturing units and in addition would also be of use to units seeking certification under international standards like OHSAS 18001 or national standards like IS 18001:2000. However, compromises are often necessary in actual practice $;$ and

Table 3: Recommendations for tables in readymade garment units

\begin{tabular}{llcc}
\hline Parameters & Cutting table & Sorting table & Checking table \\
\hline Length & $\begin{array}{l}\text { Variable depending upon the size of the room and the } \\
\text { length of the lay }\end{array}$ & $180 \mathrm{~cm}(6 \mathrm{ft})$ & $180 \mathrm{~cm}(6 \mathrm{ft})$ \\
Width & $120 \mathrm{~cm}(4 \mathrm{ft})$ The maximum width of fabric & $120 \mathrm{~cm}(4 \mathrm{ft})$ & $120 \mathrm{~cm}(4 \mathrm{ft})$ \\
& & & $90 \mathrm{~cm}(3 \mathrm{ft})$ \\
Height for men & $117.3 \mathrm{~cm}$ & $112.3 \mathrm{~cm}$ & $117.3 \mathrm{~cm}$ \\
Height for women & $108.9 \mathrm{~cm}$ & $103.9 \mathrm{~cm}$ & $108.9 \mathrm{~cm}$ \\
\hline
\end{tabular}


these guidelines, which are normative, will be of relevance in reducing the strain of work.

\section{REFERENCES}

1. Uchikawa S. Indian Textile Industry, State Policy, Liberalization and Growth. Manohar Publications: New Delhi; 1998.

2. Awasthi M, Singh A. Global competitiveness hinges on product quality. The Textile Magazine 2003;44:42-3.

3. Courtney TK, et al. The impact of a chair as an ergonomic intervention in conventional trouser manufacturing. Georgia Inst Technol: Atlanta; 1990.

4. Blader S, Barck-Holst U, Danielsson S, Ferhm E, Kalpamaa M, Leijon $\mathrm{M}$, et al. Neck and shoulder complaints among sewing machine operators: A study concerning frequency, symptomatology and dysfunction. Appl Ergon 1991;22:251-7.

5. Nag A. Women in industry - Repetitive work and postural stress. In: Nag PK, (Ed). Ergonomics and work design - Emerging issues in organizational sciences. New Age International Pvt. Ltd: New
Delhi; 1996.

6. Delleman NJ, Dul J. Ergonomic guidelines for adjustment and redesign of sewing machine workplaces. In: Haslegrave CM, Wilson JR, Corlett EN, Manenica I, (editors), Work design in practice. Taylor and Francis: London; 1990.

7. Parimalam PN, Kamalamma, Ganguli AK. Hazard identification and risk assessment in garment manufacturing units. Proceedings of conference on humanizing wok and work environment. Mumbai, India: 2004. p. 93-7.

8. Grandjean E. Fitting the task to the man - An ergonomic approach. Taylor and Francis: London; 1985.

9. Ghosal S, Chakrabarthi D. An ergonomic study on the ready-made garment workers at Ahmedabad for improvement of health, safety, efficiency at work and productivity. National Institute of Design: Ahmedabad; 1987.

Source of Support: Nil, Conflict of Interest: None declared.

\section{Author Help: Sending a revised article}

1) Include the referees' remarks and point to point clarification to those remarks at the beginning in the revised article file itself. In addition, mark the changes as underlined or coloured text in the article. Please include in a single file
a. referees' comments
b. point to point clarifications on the comments
c. revised article with text highlighting the changes done

2) Include the original comments of the reviewers/editor with point to point reply at the beginning of the article in the 'Article File'. To ensure that the reviewer can assess the revised paper in timely fashion, please reply to the comments of the referees/editors in the following manner.

- There is no data on follow-up of these patients.

Authors' Reply: The follow up of patients have been included in the results section [Page 3, para 2]

- Authors should highlight the relation of complication to duration of diabetes.

Authors' Reply: The complications as seen in our study group has been included in the results section [Page 4, Table] 